\title{
A DESIGN QUEST WITH MECHANICAL TOOLS
}

\author{
Uğur TUZTAŞI \\ Sivas Cumhuriyet Üniversitesi, Türkiye \\ ugurtuztasi@cumhuriyet.edu.tr \\ https://orcid.org/0000-0003-3668-5665 \\ Pınar KOÇ \\ Sivas Cumhuriyet Üniversitesi, Türkiye \\ pinarkoc85@gmail.com \\ https://orcid.org/0000-0001-8727-2655
}

\begin{abstract}
This study is a design quest and transforms mechanical tools into an architectural production. In architectural design, formal searches are the most challenging feature of developing different design strategies. As a main design facility, mechanical tools manipulate design research, design and design action in this studio. The pedagogical method of this study is shaped by the concepts of "reflection-inaction" of Schön and "research through design" of Frayling. Doing by thinking and thinking by doing are employed as effective experimental tools of formal researches and design mechanism. In addition, the mechanism of perception and abstraction is employed concurrently in the design quest. The method of the studio is as follows: mechanical tools are described by touching, turning about, twisting and measuring in the studio and, thus, the object's features are defined by perceptual selectivity. Subsequently, sectional diagrams of mechanical tools are revealed and spatial depth is explored in terms of function and other architectural design dynamics. In addition, visual and mental thinking are activated by abstraction, reduction, addition, removal, rotation, dismantling, reshaping, fragmentation and, sometimes, imitation, while the design quest is conducted through doing and thinking. All of this process is carried out for the purpose of obtaining a consistent and holistic architectural design. Through this study, alternative design approaches and formal searches are derived from mechanical tools. Consequently, this experimental production is making a contribution towards helping students to develop their mental and visual design ability with regard to establishing an alternative relationship between the spatial narrative and the formal mechanism in an architectural studio.
\end{abstract}

Keywords: Architectural Studio, Design, Form, Mechanical Tools, Pedagogy.

\section{MEKANIK ARAÇLARLA BİR TASARIM ARAŞTIRMASI}

\section{ÖZ}

$\mathrm{Bu}$ çalışma bir tasarım araştırmasına dayanmaktadır ve mekanik araçların, mimari tasarım ürününe dönüşümünü konu almaktadır. Mimari tasarımda biçimsel araştırmalar, farklı tasarım stratejilerini geliştirmek hususunda en çetrefilli konudur. Bu stüdyoda, temel bir tasarım aracı olarak mekanik araçlar, tasarım araştırmasını, tasarımı ve tasarım edimini yönlendirmektedir. Çalışmanın pedagojik yöntemi, Schön'ün "reflection-in-action" ve Frayling'in "research through design" kavramlar1 aracılığıyla biçimlendirilmiştir. Düşünerek yapmak ve yaparak düşünmek, biçimsel araştırmaların ve tasarım mekanizmasının etkili deneysel bir aracı olarak kullanılmıştır. Ayrıca, algı ve soyutlama mekanizmaları da tasarım araştırmasıyla eş zamanlı olarak kullanılmıştır. Çalışmanın yöntemi şu şekilde ilerlemiştir: Mekanik araçlar, stüdyoda, dokunarak, evirip çevirerek, eğip bükerek ve ölçerek betimlenmiş ve böylece nesnenin özellikleri, algısal seçicilik aracılığıyla tanımlanmıştır. Mekanik araçların kesit diyagramları çıkarılmış ve işlev ve diğer mimari tasarım dinamikleri açısından mekansal 
derinlik keşfedilmiştir. Böylece, tasarım araştırması yapmak ve düşünmek aracıllğıyla yürütülürken görsel ve zihinsel düşünce, soyutlama-ekleme-çıkarma-döndürme-deforme etme-yeniden şekillendirme-parçalama ve bazen de taklit aracıllğıyla etkinleştirilmiştir. Tüm bu süreç, tutarlı ve bütüncül bir mimari tasarım elde etmek amacıyla yürütülmüştür. Bu çalışma aracıllğıyla, mekanik araçlardan alternatif tasarım yaklaşımları ve biçimsel araştırmalar türetilmiştir. Sonuçta, bu deneysel üretim, mimari stüdyoda mekansal anlatı ve biçimsel mekanizma arasında alternatif bir ilişkinin kurulması açısından öğrencilerin zihinsel ve görsel tasarım yeteneklerini geliştirmelerine katkı koymuştur.

\section{Anahtar Kelimeler: Mimari Stüdyo, Tasarım, Biçim, Mekanik Araçlar, Pedagoji.}

\section{INTRODUCTION}

This paper considers an alternative formal research in an architectural design studio. For this purpose, a design quest was created which centered around mechanical tools. Mechanical tools have highly inspiring tectonic and aesthetic elements as industrial design objects. Mechanical tools as design objects are structured within a purpose to contribute functionally to a device. This functional orientation on the machine has been turned into a design research for this paper. For example, in this research, beyond the function of a tool designed as a repair or part of a mechanical tool, it was studied as a design object as a formal source of a spatial problem in an architectural studio environment and a design product was developed in this direction. The machine, designed with a fully functional orientation, entered the architectural studio with some conditions, of course. Accordingly, it was important that the machine part or mechanical tool was portable, its functional arrangement was clear and understandable and it consisted of different structural components.

To clarify, this paper mainly aims to invent a new pedagogical method to develop different design strategies for formal searches in architectural design. Architectural design is not just a form-oriented process and a final product. However, ultimately, the point reached by the architectural design process is a mass organization defined by consistent and holistic relationships. The main aim of this text is to make the form the main concern of the design research and to look for ways to transform an object outside the field of architecture into an architectural design complete with functional-contextualstructural-tectonic relations. This area of interest results from making the design process understandable. This is based on two concepts. The first concept is "reflection-in-action" put forward by Donald Schön. According to Schön (1983: 68), anyone is able to becomes a researcher in a practical context, but, in the case of reflection-in-action, the researcher is not dependent on the existing theories and techniques. $\mathrm{He}$ builds a new theory unique to his situation and does not distinguish thinking from doing. The concept of "reflection-in-action" portrays the design process as a sequence that frames the focused context by making temporary design decisions, evaluating and reframing these design decisions in terms of expected results and/or new situations (Michels and Meeus, 2013: 193). This means that there is a process by which the designer thinks about the design decisions and re-thinks by doing them. The creation of a formal configuration in the architectural design process creates a cognitive mechanism that feeds between thinking and doing, which makes the method of this text operable. It should be stated here that the design process is continuous and the solution may not have a logical outcome of the problem, moreover, there is no operational sequence to guarantee the result (Lawson, 2005: 123-124).

The second concepts of this study are "research into design", "research through design" and "research for design" developed by Frayling (1993/4: 5). Accordingly, while "research through design" marks the research and development that emerges as part of the practice; "research for or into design" focuses on questions related to the role that professional practice will play in the construction (Salama, 2015: 46). Moreover, starting from Frayling, new insights, such as "research by design", have been developed. "Research by design" is concerned with the interconnected aspects of research and design when we produce new information through the act of design (Hauberg et al., 2013: 336). This means that, within the scope of research and design, there is a development route that is learned from practice and fed from practice. As research on design takes place through a practical act, research evolves into a process that needs to be redesigned. This text, which aims to make the form the main area of design research, has

Research Article - This article was checked by iThenticate 
tried to use the "reflects-in-action" situation in the architectural studio through "research through design".

On the other hand, the main object of the pedagogical method of this study is mechanical tools. Mechanical tools, which are the basic materials of the method, appear in another study. The previous study, which took a different path from the method on which this text is based, was essentially the product of a methodology that examined the possibilities of computer use as a design tool, and the study was designed to enable new designers to develop their education and habits that would affect their professional lives (Lin, 2012: 59). This text focuses on developing a pedagogical approach to formal searches in architectural design through mechanical tools. In architecture, the form does not directly refer to a geometric shape. The shape is a design affair but the form is an imagination of integral parts (Johnson, 1994: 335). In this study, the main object of the design research was made in the mental mechanism, which was processed mechanically, affectively and cognitively. Ways to create a formal configuration in architectural design with those reflected on the object (mechanical tools) have been tried. In this process, perceptual effectiveness and the way this performance appears in design research are important.

\section{LITERATURE REVIEW FOR INQUIRY}

Finke and Slayton (1988: 255-256) revealed in a study that people make creative visual discoveries by imagining new combinations from small pieces, and also argued that the pattern of the imagined pattern does not necessarily indicate when it started to shape the image. This means that visible information, transmitted to the mind and passed through cognitive processes can turn into meaningful, holistic and consistent visual objects. As emphasized by Merleau-Ponty (2006: 26) in the context of Gestalt psychology, an object becomes evident not because of its meaning, but because of its perceived structure. Therefore, the semantic values that the images bear explicitly and/or implicitly are realized through performance based on perception. Instead of a direct way of seeing, some sort of selection takes place between the eye and the object. As Arnheim (2009: 40) states, an object's attention draws because it responds to the needs of the observer or stands out from the others. According to Kant (2015: 101), two conditions that make the information of the object possible are intuition and concept. While intuition allows the object to be given as a phenomenon, the concept enables the object that corresponds to intuition to be considered. In other words, not the ones reflected on the paper during the perception process, but the concepts that are sensed through intuition and processed in the mind are sought. In this activity, perception prioritizes the object closest to its specific experience and/or the relations it sees by conceptualizing the relationships it searches, because thinking is the act of associating the given intuition with an object (Kant, 2015: 200). In such an action, things are not simple and neutral objects, but beings that symbolize/remind us of an attitude or create a positive-negative reaction (Merleau-Ponty, 2014: 30). The basic element in the architectural design process is "form", as it will be prioritized in the correlation of the given intuition to the object and the selection of this action.

The building, which emerged as a result of the design action, has a spatial extension. While the building has a certain function and structural fiction, the form of the building exists by joining individual form elements, shapes and figures (Fischer, 2015: 61). This means that, as a result of filtering the object through perception, a holistic structure defined by interrelated and consistent relations should emerge. For such a composition to be organized, as the eye moves across the object, it senses new correlations and subordinates them to mental processing. The most dominant element that can be selected during this detection process is undoubtedly the parts of the object that differ from the other images around it. In addition to this dominant element that can be seen, the mind reveals implicitly hidden clues depending on the conceptualization and perceptual skill capacity of the thinking process. According to Goldschmidt (1991: 127), we can provide direct access to clear information in visual images that assist in reasoning, as well as those in the same images that do not exist explicitly. Perceptual organization, which does not limit itself directly to the given material, thus records invisible extensions as the real parts of what is visible (Arnheim, 2009: 50). In other words, the form does not only emerge with the appearance of the object, but it is also deciphered with new pieces of content and meaning loaded. This is due to the

Research Article - This article was checked by iThenticate 
perception that the concept is an organized structure rather than a mosaic of elements (Arnheim, 2009: 57).

Fischer (2015: 14-15) emphasizes that, according to the basic principle of perception psychology, the meanings and effects of individual elements are changed by the context in which the elements are perceived, and that the emergence of new things depends on the way the elements are brought together. This means that all the implicit and explicit relationships in the object are transformed into a new fictional form that the first image does not possess but the product contains, through the values that are added-subtracted-abstracted-reduced-transformed and reconstructed according to the mental activity level of the perceiver. In this configuration, it is important how the current state of the object is read. More specifically values, such as proximity-distance, direction-orientation, interior-exterior, clusteringcoexistence, coincidence-decomposition, centralization-decentralization, angle, measure and ratio help to create a category of information related to the design. Thus, the process of form formation can be depicted as a series of subsystems, all of which are interconnected but have sufficient freedom to adapt independently (Alexander, 1973: 43). Perceptual skill and comprehension ability emerge in the process of linking these relationships, attempting to design spatial relations, structural fiction and other abstract relations through content-process-meaning-function-representation. On the other hand, Alexander (1973: 15) reports that this physical clarity cannot be achieved unless there is a programmatic clarity in the mind and actions of the designer. Therefore, he states that each design problem begins with an effort to achieve compatibility between form and content. Accordingly, every form can be defined as what it is and what it does; notion of what it is implies a formal description while notion of what it does implies functional description (Alexander, 1973: 89). The linking process in perceptual processing is thus also under the influence of the cyclic reading that fluctuates between form and content. In other words, it represents the artistic aspect of design, which is characterized by responding to visual thinking or imagination, intuition and aesthetic and emotional needs in forming a shape for most architects (Goldschmidt, 1994: 160).

Creation of a formal organization in architectural design arises through the activation of a versatile perceptual performance process. The cognitive process is sometimes stimulated with several stimuli to create a design idea. Goldschmidt (1991: 130-131) states that in a study on sketching, through sketch, the designer is preparing for a sequence of relationships between the forms that enrich the research ground and the representation of the forms. In the plural and simultaneous production, what is envisioned is divided into "seeing as" if the designer includes formal or gestalt judgments, and the designer, "seeing that" if developing non-formal judgments. In other words, all formal features on the sketch are evaluated together with their visible and invisible extensions. Defining new relations between objects or transforming existing images takes place and is entirely dependent on the horizon of the perceiving subject. For example, in a study conducted by Verstijnen et.al. (1998: 524-525), it is stated that during mental imagination, significant difficulties were encountered in reconstructing and/or combining the first concept of a pattern and therefore new information was discovered in the mind. Such a dynamic relationship marks perceptual leaps and formal transformations that manipulate reasoning for design in the formation of the formal composition.

In design research, the creation of the form on the path to the result is carried out by processing a descriptive/analytical/descriptive mechanism. In the process leading to the formal composition in architectural design, the composition of the object can be processed in pieces, depending on the perceptual skill capacity, a new whole can be obtained from the pieces, new relations can be defined between the pieces, and/or discrete stimuli can be brought together by piecemeal detection. To summarize, reaching a formal organization based on the object starts with the forms that are prioritized, distinguished and noticeable under the specific experiences in the perceptual process. After the formal transformation that started according to the content and semantic values loaded under the design research, it is constructed with explicit/implicit extensions. The perceptual experience subjected to thought triggers the cognitive processes, from the parts to the whole and from the relations between the parts to the holistic structure. The resulting product may be similar to the original object or may have a completely distinct appearance from it. This also requires skill-based performance and capacity utilization regarding perceptual skill and comprehension ability.

Research Article - This article was checked by iThenticate 


\section{STUDIO SETTING AND SETUP}

This study was conducted in a studio, relied on participants' observation and an investigation of the project's process and outcomes. The study's pedagogical approach considers architectural form and spatial narrative. Thus, the studio setting allowed a primary research of the design mechanism which consisted of description, recognition, abstraction and representation while the studio setup provided a secondary content of study. Mechanical tools and machine parts acquired by the tutors were moved to the studio setting (Table 1). These tools included mechanical tools such as a jack, a door lock, an automobile tube injector, a lever sharpening wheel stone and rope tensioning. At this point, it should be mentioned some features about the studio. This studio comprised of fourth-year architectural students. In the studio, there was 45 students and all of them worked this design research by themselves.

Table 1. Mechanical tools used in the method.

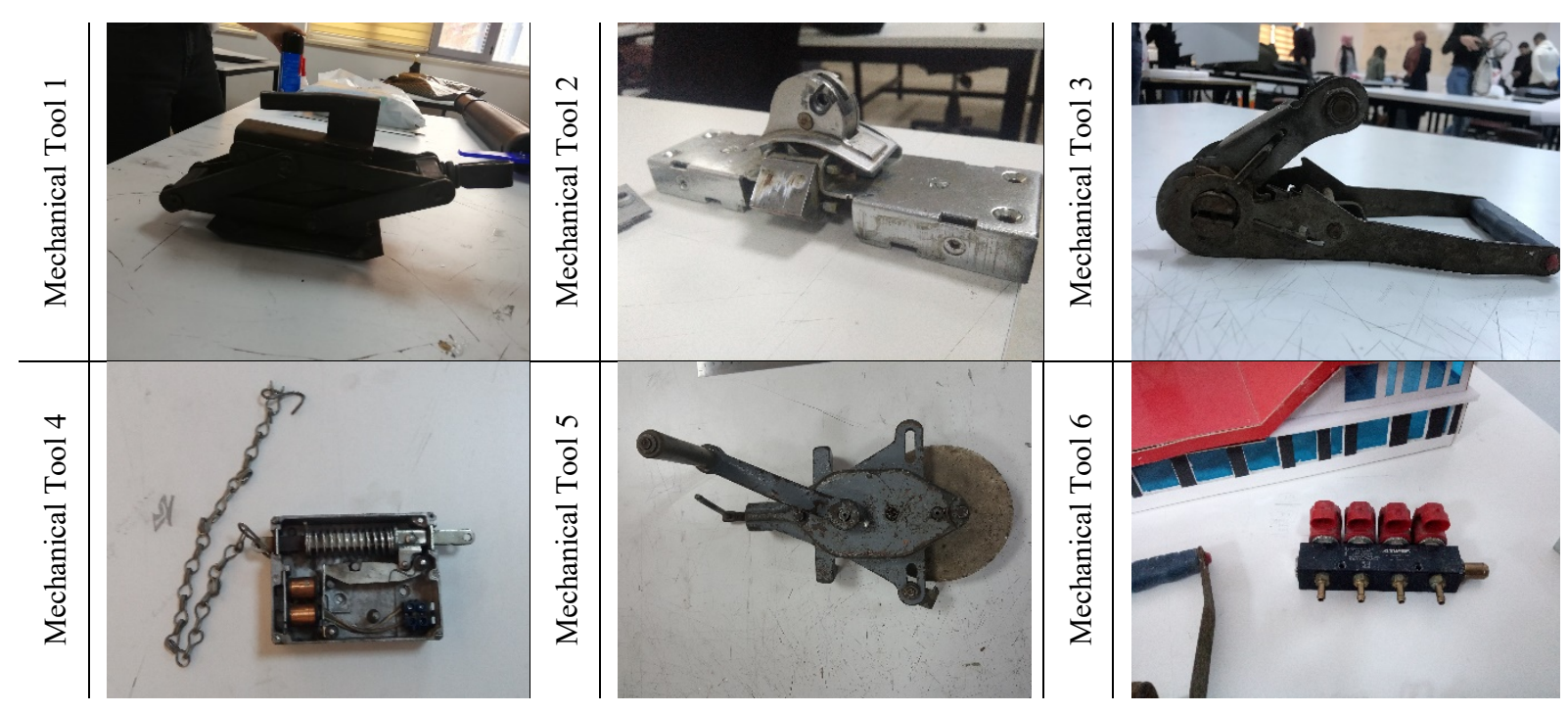

The design research process was completed in two stages. The first stage was carried out with a 4-hour sketch exam in the studio. In this process, a mechanical tool was given to each row of the six rows and this was transformed into a strategy for obtaining mass for the students in each row arrangement. This consisted of studying and sketching the mechanical tool. Before proceeding to the sketches, it was important to make time for the students to establish a relationship by touching, turning about, twisting, and measuring with a mechanical tool. In the studio, an activity milieu based on perceptual performance was provided with tools to assist visual thinking, such as abstraction-reduction-addition-subtraction-rotation-deformingreshaping-fragmentation (Table 2). 
Table 2. Scenes from the studio and pedagogical method.

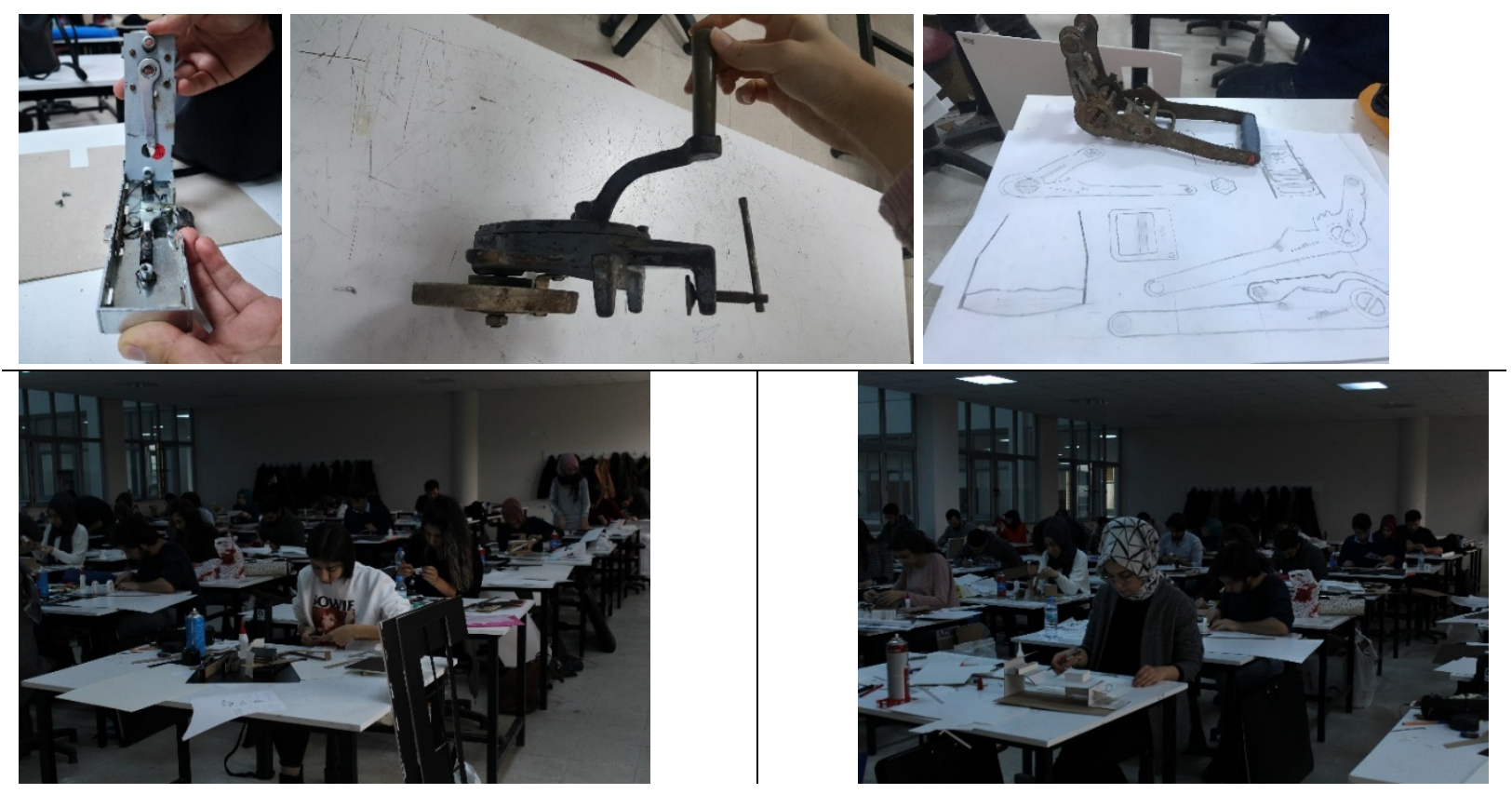

This process, which was shaped around the mechanical tool, was the description of the object. Students, who knew the mechanical tool, started to search for the design which was their main task in the next stage. Describing the object with design tools such as section and model left a place for the creation of spatial narration in the search for design. The process continued in the direction of inventing components such as spatial narrative, depth and alignment and, this time, the mechanical tools brought to the human scale served as the design resource. In this studio, where mostly cross-section diagrams and models are studied, mechanical tools have gradually evolved into an environment where the boundaries are defined over the cross-section diagrams, the compactness-emptiness balances are created and the ground layer is analyzed topographically. This first 4-hour process started in the studio and was completed with the first studies to acquire the design idea, and the other half of the process was carried out as a research paper. In order to provide flexibility and adequate internalization of the design ideas, the research paper was spread over three weeks and the search for a design continued on the mechanical tool. With this method, mechanical tools transported their design resources to the search for design and spatial organization, and a different pedagogical initiative was realized in the design of the formal mechanism in the architectural studio education.

In addition, learning outcomes from the studio should be mentioned. The studio setting and setup led students to identify a design object and transform it to an architectural product. It was clarified in the studio setting that an architectural form could be obtained from various sources. Also, it was discovered that relationships between the spatial narrative and other architectural dynamics could be established in different ways. Contrary to traditional architectural studios, this study provided a wide range of design research options as alternatives and an experimental studio. Therefore, the content of the studio and the pedagogical approach as a unique sample was different from traditional studios and provided more diversified relationships of the architectural product. 


\section{STUDIO PROCESS, STUDENTS' WORK AND OBSERVATIONS}

The results of the design research, which started with six different mechanical tools in six rows, were collected separately for each mechanical tool. First, three results that would start design research on the first mechanical tool, the mechanical car jack, were shared. In the first example, there was a project that functioned as a chalet. In this design research, the design strategy was developed by focusing directly on the mechanical tool. Sorting was performed on the tool in terms of its parts and the mechanical tool was extracted as tectonic parts, functional parts and auxiliary parts. While the ground layer and complementary structural components, such as ramps, terraces and towers, were created from tectonic parts, the circulation scenario of spatial organization was produced from the functional parts. Auxiliary parts that hold the mechanical tool together were considered as a limiting element in the design and were converted into components that defined depth, orientation and boundary (Figure 1).

In the second design example that dealt with the first mechanical tool, a strong abstraction of the mechanical tool was made. Perceptual selectivity was introduced to form the design strategy and the angled surfaces on the side of the mechanical tool were subjected to a linear deformation. Linear extensions of the mechanical tool were included in the design strategy by providing a strong stratification in the horizontal and vertical directions. Functioning as an architectural office, the project offered an extension within the city with its dynamic pattern and vertical extension. The third example sought to transform the mechanical tool into a design strategy with a reducing attitude. The most effective activity for this process was to draw a direct section diagram of the mechanical tool and express it as a model. Here, understanding the mechanical tool as a complete entity appeared. However, this did not directly affect the design strategy, but, on the contrary, the mechanical tool, whose cross-section diagram was drawn and expressed as a model, was rotated $90^{\circ}$ and the resulting configuration was used in spatial analysis. The design research carried out with the first mechanical tool revealed that the processes of reduction-deformation-inversion-translation through direct quoting and perceptual selectivity diversified the spatial narrative (Figure 1). 

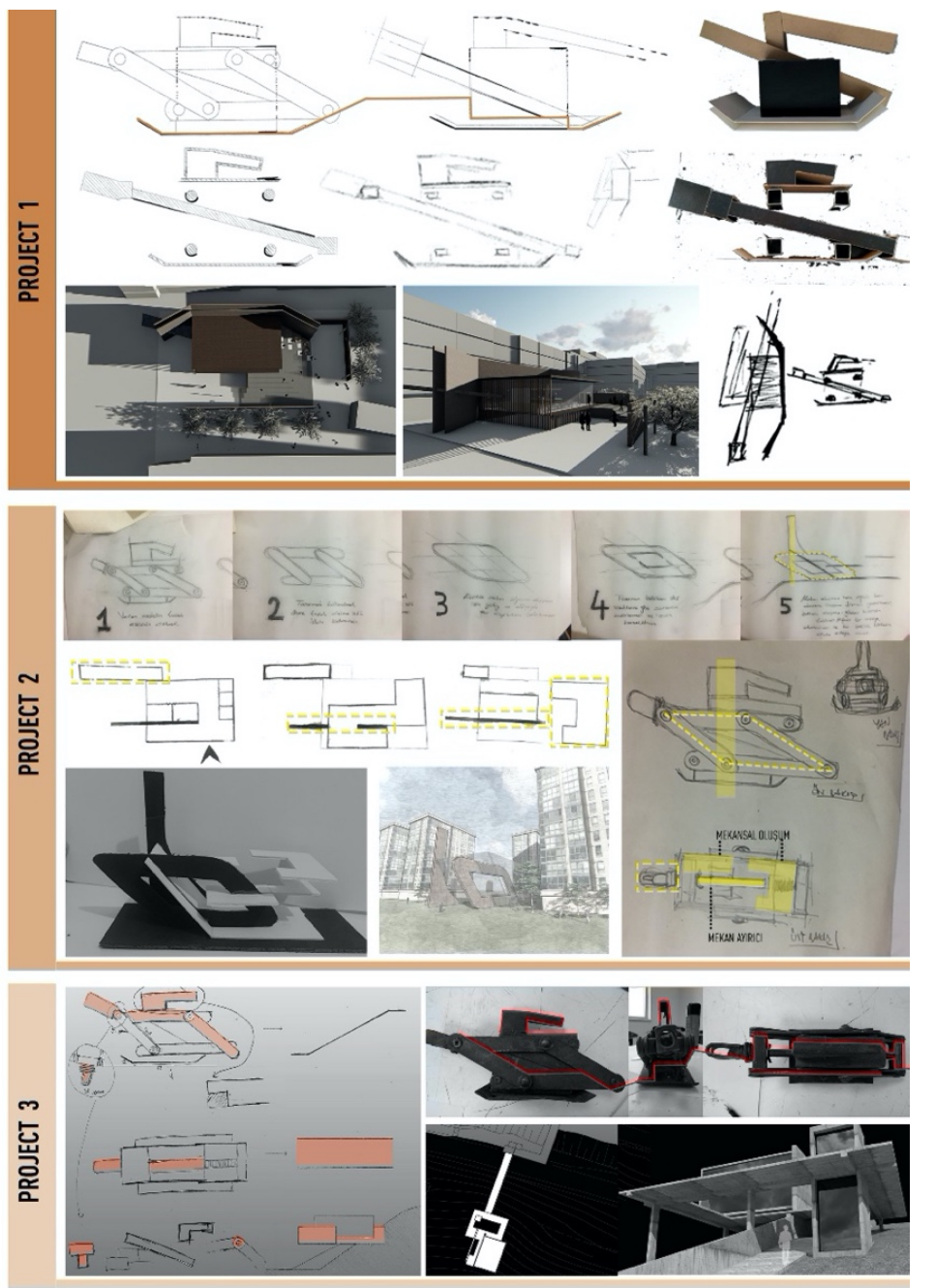

Figure 1. First Mechanical Tool: description of the object and creation of the spatial narrative in the search for a design.

The second mechanical tool was a door lock mechanism. The design strategy of the first example was shaped by the section diagram obtained along the horizontal extension of the mechanical tool. The surfaces of the mechanical tool by opening and reversing were dismantled and the surfaces described with a reducing approach were used in the mass configuration. Here, an elective language of conscious choices for spatial narrative dominated the design strategy. In the second example, a preliminary study was carried out for the mechanical tool for the resolver and the disassembler. The resulting product, however, emerged as a spatial narrative created by direct quoting. As a matter of fact, the mechanical tool, which was separated and examined in the preliminary study phase, underwent a mass transformation without resorting to abstraction tools that help visual thinking. Accordingly, the outer boundary lines of the object were accepted as the boundary of the architectural mass and the compactness-emptiness relations within the mechanical device contributed to the formation of the closed-open space fiction in the spatial narrative. The main problem in both examples formed on the second mechanical tool was that the analysis step could not be advanced. The architectural student who smashed, opened, looked, inverted and turned the mechanical tool had a hard time turning the object he described into a consistent spatial narrative and formal imitation interceded, instead of effective perceptual performance in design (Figure 2). 


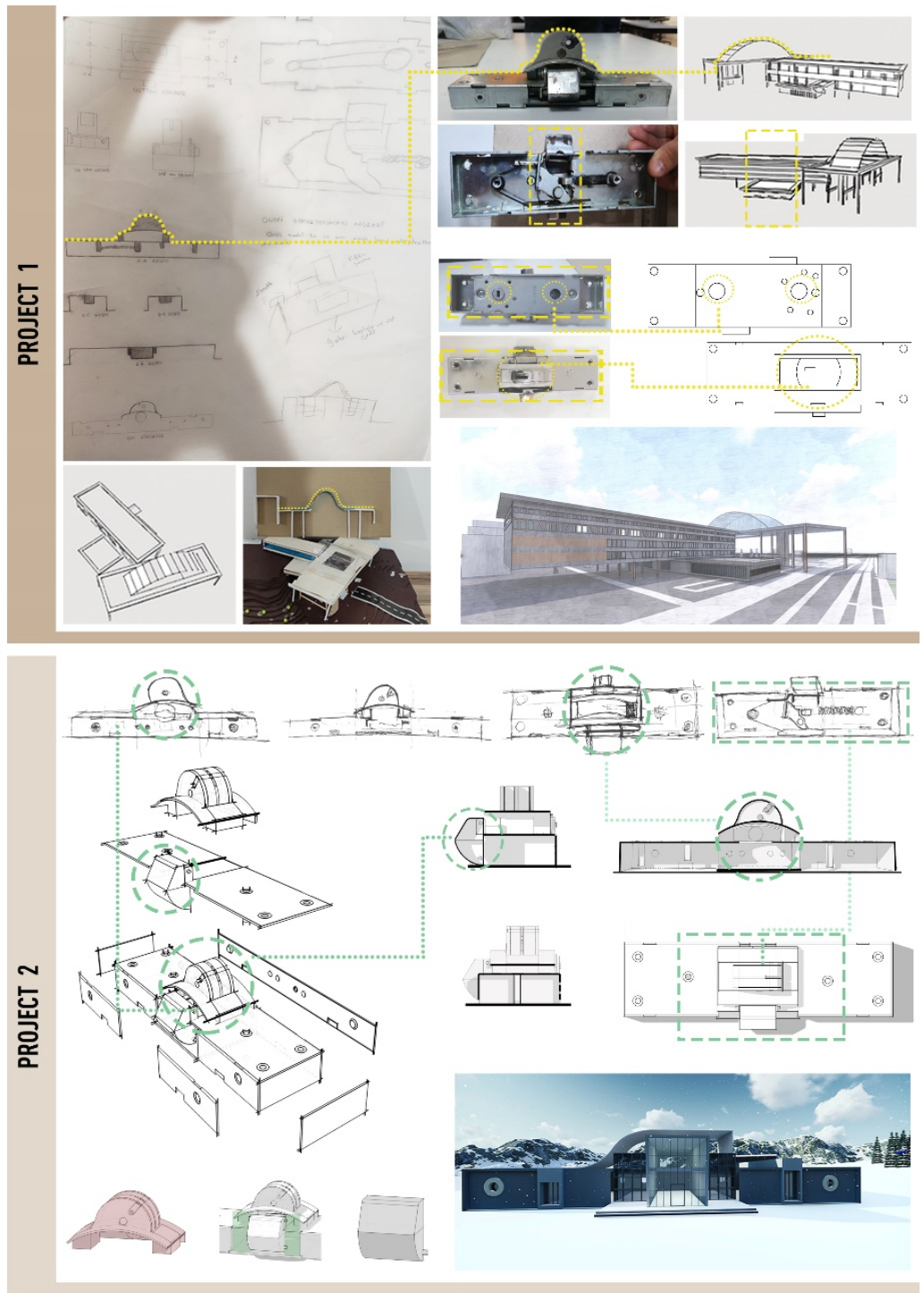

Figure 2. Second Mechanical Tool: description of the object and creation of the spatial narrative in search of a design.

The third mechanical tool, unlike the other two mechanical tools, was the mechanism used for rope stretching with a more flexible and unstable structure. Based on this feature, the first example of design research addressed the collapsible, foldable state of the tool as a dynamic design component. The first example, which functioned as an auto gallery, prioritized the complete disintegration of the mechanical tool in its design strategy. After all the components that made up the mechanical tool had been disassembled and sketched, cross-section diagrams were created to form the spatial narrative. A silhouette was removed from the view obtained by turning the mechanical tool $90^{\circ}$ and this was integrated into the mass organization. Therefore, in this example, a highly effective design mechanism and process was revealed and the mechanical tool was included in the spatial narrative by dismantling and inverting instead of abstraction or direct quotes. In other words, in the design strategy, there was a search for a new language of form from the mechanical tool (Figure 3). In the other example developed on the third mechanical tool, there was a similar dynamic transformation history. However, unlike the other, abstraction was realized over reduction. The state of the mechanical tool in different positions obtained by opening-closing was modeled in section diagrams. The state of the mechanical tool in each position was studied separately as a mass organization on the sketch and the parts were dismantled in horizontal and vertical stretches and placed in the topography. In this example, the process of depicting the object resulted in inventing spatial depth and sequence (Figure 3).

Research Article - This article was checked by iThenticate 


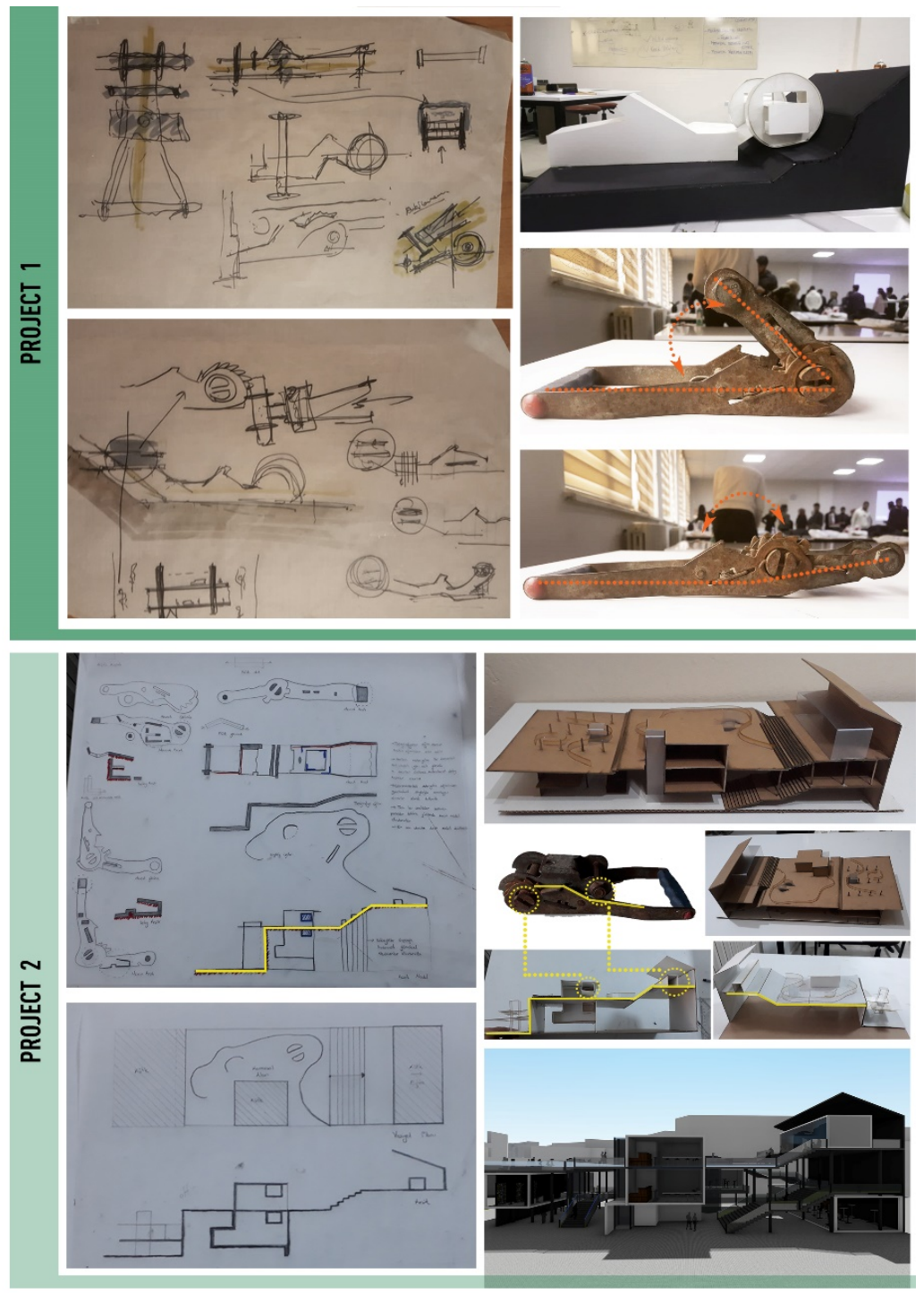

Figure 3. Third Mechanical Tool: the description of the object and creation of spatial narrative in search of design.

In the design research process of the fourth mechanical tool, the automatic door lock mechanism, it was observed that the design samples showed an approach derived mostly from the separation of the parts. Each disconnected mechanical part was created as a design strategy by detaching the functional-tectonic mechanism it created within the whole. In the first two examples, the final product was achieved with a completely disruptive and reinterpretable mass organization, while, in the last example, which set off with the same design strategy, there developed an understanding that ultimately resembles all the spatial components acquired in the search for a design (Figure 4). Accordingly, with the first example the mechanisms that provided the mechanical tool operability were disconnected and placed in a grid planimetric organization. These pieces created spatial components that were permeable and open to interaction in the mass organization and provided the prismatic order of the closed spaces in the planimetric establishment. Apart from the prismatic bodies in the grid layout, the remaining part was designed with a full-space balance. In this example, the functional components were broken down from the mechanical tool and were used without abstraction and a new language of form was created with the traces formed by its formal frame. In the second example, the process of describing the object was reflected in the design of the language of the form. By searching the functional-tectonic parts of the mechanical tool, a design was searched for based on which function and how a spatial component can be transformed into the mass organization. As a result, the mechanical tool, which was turned into a

Research Article - This article was checked by iThenticate 
university entrance gate, was transformed into a design product through borders, closed spaces and passages, with a particle perspective. In the last example, while following the similar fragmented design strategy like the other two examples, the tectonic simulation of the resulting product resulted in clear visibility of the structural elements. All the functional, complementary and limiting elements of the mechanical tool were disconnected and each was evaluated as the prominent element of the structure in the mass organization.

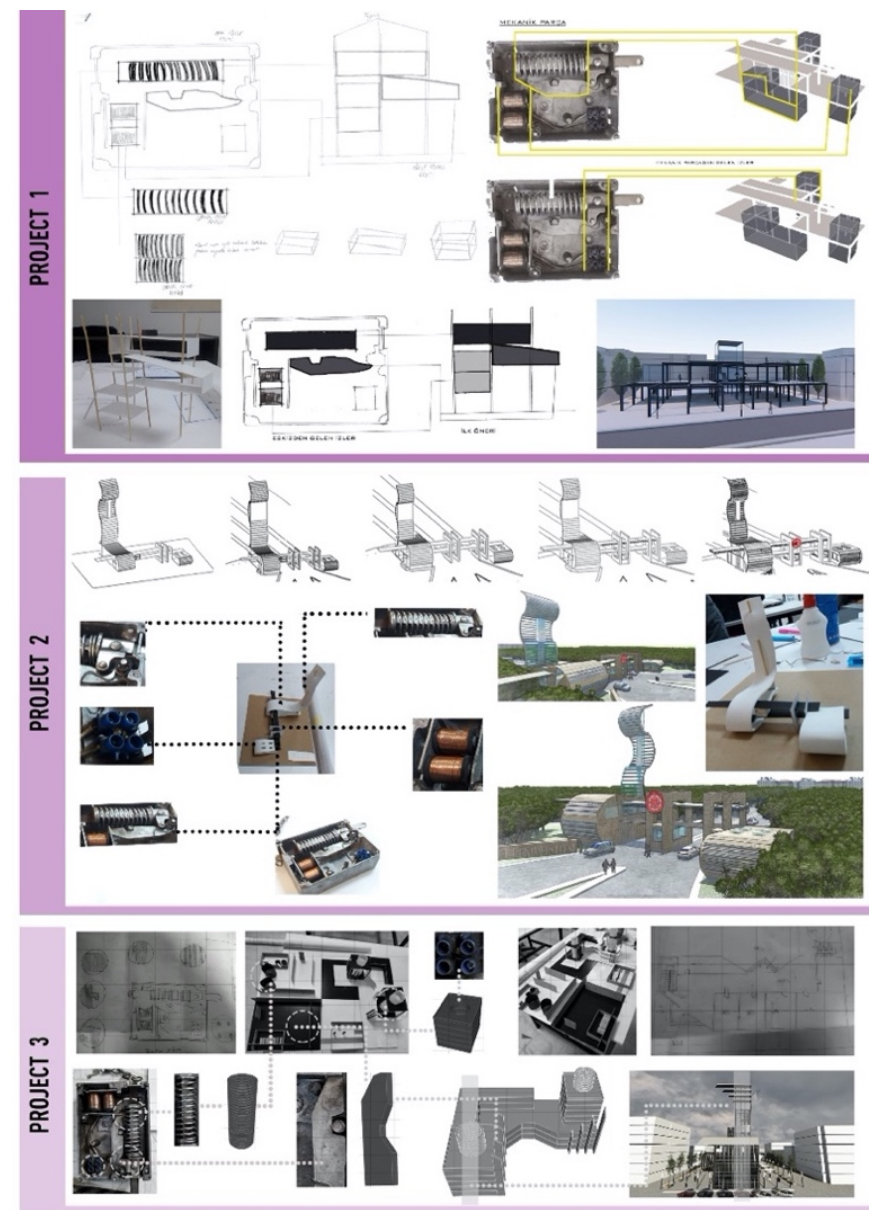

Figure 4. Fourth Mechanical Tool: description of the object and creation of a spatial narrative in search of a design.

It was observed that the designs dealing with the fifth mechanical tool, known as the lever sharpening wheel stone, were abstracted by characterizing the spatial stretches in the vertical direction established between the different elevation planes. This is probably due to the structural composition of the mechanical tool. In all three examples studied, the boundaries of the mechanical tool, the junction details of its superimposed parts and the stratified angled planes in the whole of the tectonic organization were the main components of the design strategy (Figure 5). For example, the first project presented the horizontal and vertical borders between the superimposed parts of the mechanical tool as a section diagram and expressed these in an abstract manner with a small model of work. All the linear components in the language formation emerged as a composition of the surfaces that formed the boundary of the mechanical tool. The second example developed a design understanding between the vertical distance between the components of the mechanical tool and the horizontal distance between the junction details of the parts. That is, the distance or the positioning hierarchy between parts was moved to the section diagrams and the linear components obtained were evaluated as formal language input in the mass organization. In the third example, complete linear corrosion was performed on the mechanical tool. Developing a permeable design understanding between negative space and positive space, the project followed a design strategy that shaped the language of shaping together with the 
ground layer. The example, which strongly interfered with the topography, was characterized by the differentiation of the vertical orientation between the planes and the dimensional change between the different components of the mass.
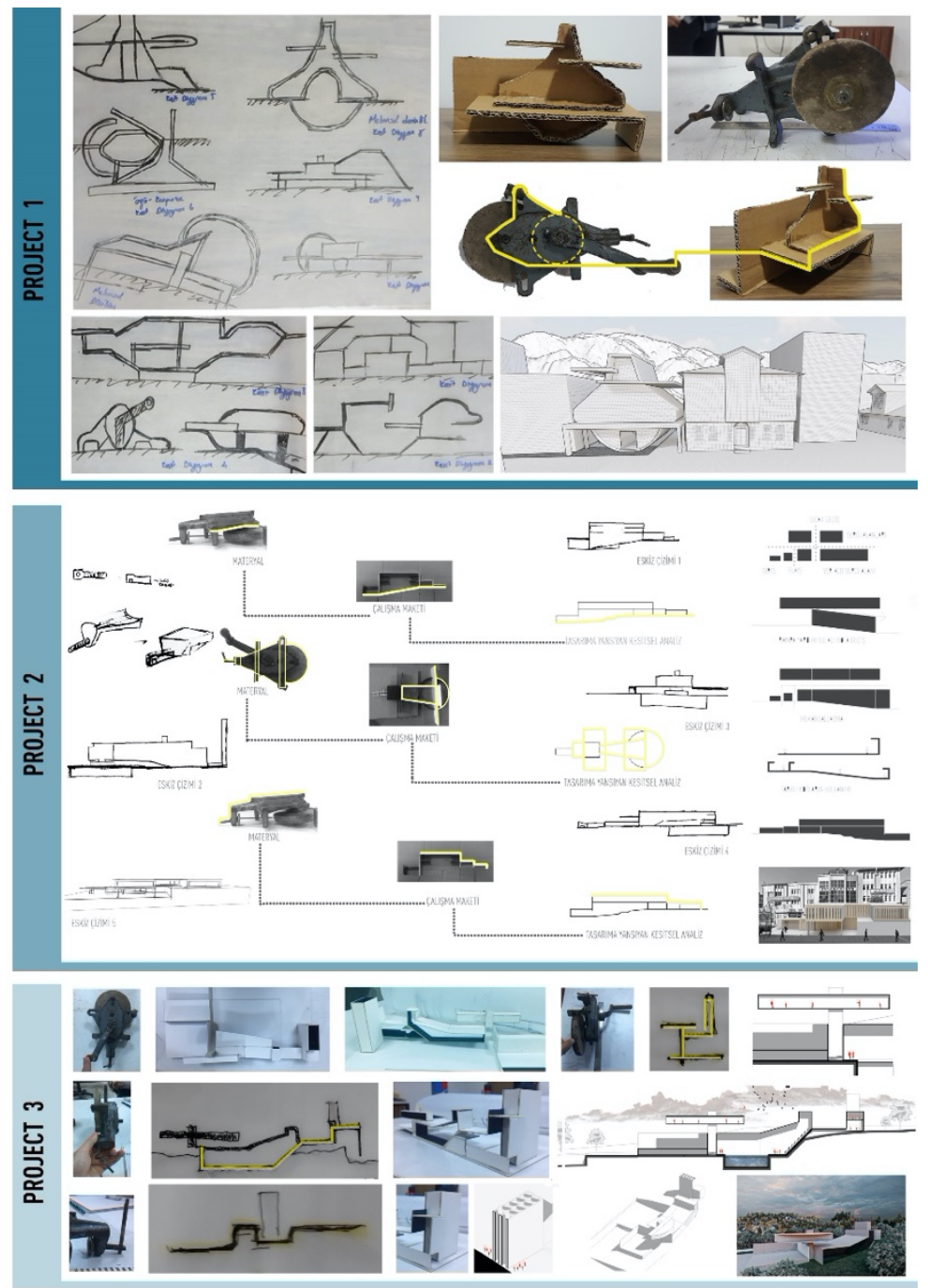

Figure 5. Fifth mechanical tool: description of the object and creation of the spatial narrative in search of a design.

In the design fiction for the sixth mechanical tool, namely the tubing injector, two different orientations emerged. The first was to describe the object through section diagrams by examining the parts of the mechanical tool directly. In the search for this design, all fixed, mobile, functional or auxiliarycomplementary parts that made up the object were determined, and then the ways of these parts coming together and their positions on the mechanical tool were studied. The second orientation, on the other hand, did not only question the description of the object over the part-whole relationship but also referenced the potentials of the material that formed the stratification and the mechanical tool over the combination details (Figure 6). 


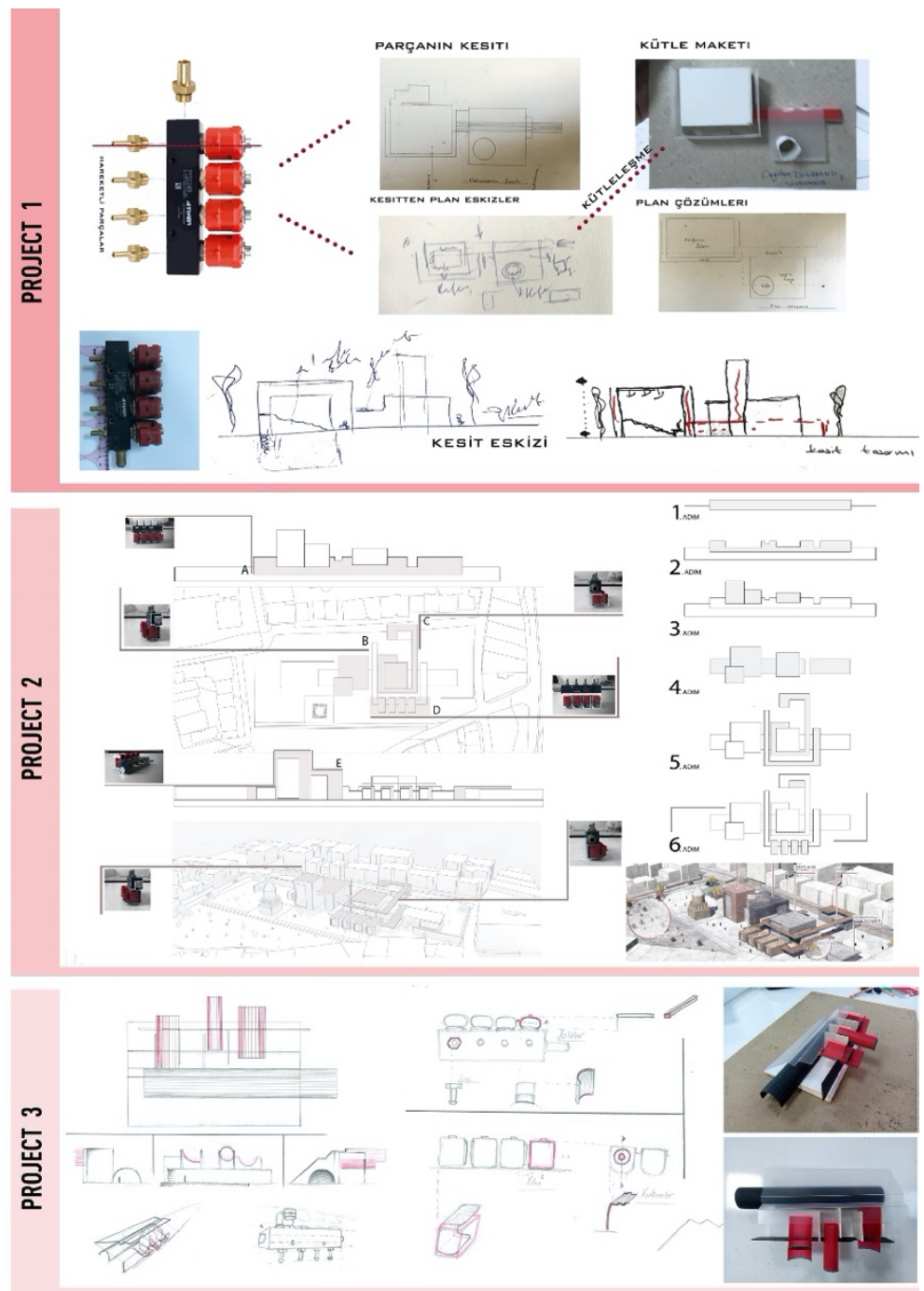

Figure 6. Sixth mechanical tool: description of the object and creation of the spatial narrative in search for a design.

Accordingly, the first example went through exploring the detachable parts of the mechanical tool during the description of the object. The project, which produced holistic section diagrams, used it as a rigid forming texture without separating all the fixed elements of the mechanical tool. The moving parts of the mechanical tool were cut from the whole and turned into a vertical structural element. In the project, where an extremely rigid geometric order was obtained, the abstractive point of view revealed a product result diverging from the formal language of the mechanical tool. The second example was shaped by the second orientation of the mechanical tool, which was the subject of the design research. The description of the object was studied through the potentials of the part and material relations. Complementary elements of the object, such as composition details, layering and color use, were posted into the formal braid in the design strategy. The two main parts of the mechanical tool and the connection details on the side surfaces were included in the search for shaping in the project as a geometric mechanism. Strong section diagrams in the project were made a part of the spatial narrative and the design concept was fed with different dynamics. While the resulting product offered a multi-part-multiunit spatial array of prismatic bodies such as a mechanical tool; unlike the rigid structure of the mechanical tool, the forming language was created with the balance of compactness-emptiness between open-semi open-closed space. The third example developed a design strategy similar to the first example, reflecting the particle relationships obtained by describing the object into the spatial narrative through perceptual selectivity. The resulting product was created with a deconstructed language of the mechanical tool that was reduced and its parts dismantled. All relations obtained by extracting the parts 
and composition details on the mechanical tool were brought together as the main elements of the mass and spatial sequence.

\section{CONCLUSION}

In this study, which set out to develop a different design strategy for formal searches used in architectural design, the main goal of the experimental production was the development of perceptual trends. In architectural education, the management of design studios with various experimental fictions is a current issue that is an effective experimental tool of architectural form, research and design mechanisms. On the other hand, studies on the development of formal mechanisms and visual perception in the creative design process of architectural education are dealt with by various conceptual studies. This research was trying to develop an architectural form production by means of mechanical tools, each of which has different design accessories but is designed for specific functionality. The design objects, which are exemplified as the formal input of a spatial problem in the architectural studio, were distributed to student groups and a process that was gradually sequenced from form production to space production was provided. In the mental mechanism processed affectively and cognitively within the scope of the study, it was a determining factor at the design level to question the mechanical tools, which were the main objects of the design research, with all implicitly explicit design relations. Since design clues in object reconstruction are related to students' perceptions and levels of mental activity, examples that question the approaches, such as addition, subtraction, abstraction and reduction with a conceptual mechanism, were tried to analyze the design inputs stored by the image in the process of transformation from a mechanical tool to a spatial form configuration. When the samples evaluated in the research were evaluated in accordance with the production style, it was observed that the effort to obtain a consistent and holistic formal mechanism fed through the perceptual selectivity of the object came to the fore. In architectural design education, it was determined that an inquiry over a three-dimensional design object contributes to design production instead of analytical analysis over two-dimensional images.

Finally, concepts of "reflection-in-action" of Schön and "research through design" of Frayling will be evaluated from the perspective of this study. Findings of this study implies that cognitive process in design was activated by doing-thinking tools. This result is directly related to spatial narratives and varies architectural solutions. Design research is conducted and revealed by perceptual performance. Mechanical tools in this studio were deformed and reformed strongly while some of them were formed by imitation or resemblances. In terms of perceptual performance this means that visual and mental thinking are activated. Tools such as abstraction, reduction, addition, removal, rotation, dismantling, reshaping, fragmentation and imitation were the main part of this design research since the cognitive process was peaked in the studio. Also, design activity in the studio was changed because of the direct and integrated part of doing-thinking processes. Research question was directly necessitated the contribution of design strategies. It means that design and design act were the primary research tool. On the other hand, concept of "reflection-in-action" of Schön indicates a strategic research and reflective researcher based on doing and thinking. This means that designer in the studio builds a new way that unique to him/her. In exactly the same way of this study, designer builds his/her own design strategy since his/her cognitive, intuitive and perceptual process are activated by doing-thinking act. In this study, mechanical tools were employed as a catalyst for activating the concept of "reflection-in-action". Thus, students in the studio were not subject to a single approach or theory. Conversely, they built their own design strategy since the doing-thinking process was unique to each student. In addition to this, concept of "research through design" of Frayling indicates that practice in design is revealed as a part of research and development. This can be associated with design knowledge. Learning from practice and experiencing a design act are the primary feature of producing a design knowledge. In sum, production of design knowledge is based on practice, experience and discovery. In this study, mechanical tools were a way of production mechanism for design knowledge. Touching, turning about, twisting, measuring and sketching the mechanical tools caused students to learn from practice and experience the tool closely. Design knowledge was provided by this action. Thus, design strategies were revealed a unique way. Consequently, the study that questions production based on a form configuration and spatial transformation process from the mechanical tool has established its strategy as

Research Article - This article was checked by iThenticate 
an alternative space design approach; this experimental production contributed to the students developing ways of establishing an alternative relationship between the space-formal mechanism in the architectural design studio. In addition, they experienced different design constructions in terms of design situations, possibilities, and potentials in transforming these alternative relations into architectural spaces.

\section{REFERENCES}

Alexander, C. (1973). Notes on the synthesis of form. Cambridge, Massachusetts: Harvard University Press.

Arnheim, R. (2009). Görsel Düşünme. İstanbul: Metis Yayınları.

Finke, R.A., \& Slayton, K. (1988). Explorations of creative visual synthesis in mental imagery. Memory \& Cognition, 16(3), pp. 252-257.

Fischer, G. (2015). Mimarlık ve dil. İstanbul: Daimon Yayınları.

Frayling, C. (1993/4). Research in Art and Design. Research paper, 1(1), Royal Collage of Art, London. Goldschmidt, G. (1991). The dialectics of sketching. Creativity Research Journal, 4(2), pp.123-143.

Hauberg, J., Tamke, M. and Ramsgaard, T. M., (2013). "Research by Design-A Research and Teaching Concept", in Proceedings of the Conference Theory by Design Architectural Research Made Explicit in the Design Studio in Antwerp/Belgium, 29-31 October 2012, Faculty of Design Sciences, Artesis University College, pp. 335-342.

Kant, I. (2015). Arı usun eleştirisi. İstanbul: İdea Yayınevi.

Lawson, B. (2005). How designers think the design process demystified. London and New York: Architectural Press Routledge Taylor\&Francis Group.

Lin, T. (2012). Figure it in. Journal of Architectural Education, 65(2), pp. 59-68.

Merleau-Ponty, M. (2006). Algının önceliği ve onun felsefi sonuçları. İstanbul: Kabalcı Yayınevi.

Merleau-Ponty, M. (2014). Algılanan dünya. İstanbul: Metis Yayınları.

Michels, M., \& Meeus, W. (2013). A sentiment for architecture implicit knowledge in the design process. In Proceedings of the Conference Theory by Design Architectural Research Made Explicit in the Design Studio (pp. 191-196). Antwerp/Belgium: Faculty of Design Sciences, Artesis University College.

Salama, A. M. (2015). Spatial design education new directions for pedagogy in architecture and beyond. England/USA: Ashgate Publishing.

Johnson, P. A. (1994). The theory of architecture concepts. Themes \& Practices, New York: John Wiley \& Sons, Inc.

Schön, D. A. (1983). The reflective practitioner how professionals think in action. New York: Basic Books.

Verstijnen, I.M., Hennessey, J.M., Leeuwen, C. Van, Hamel, R., \& Goldschmidt, G. (1998). Sketching and creative discovery. Design Studies, 19, pp. 519-546. 